logos_i_ethos_2018_1_(47), s. 199-220

DOI: http://dx.doi.org/10.15633/lie.2557

Karolina Wiśniowska

Uniwersytet Jagielloński

\title{
Etyka bezstronności Petera Singera jako filozoficzna podstawa dla etycznego konsumeryzmu?
}

Jeśli mieliśmy szczęście urodzić się w spokojniejszej, bardziej bezpiecznej części świata, problemy głodujących czy wyzyskiwanych

Karolina Wiśniowska (1993) - filozofka, prawniczka, studentka międzywydziałowych indywidualnych studiów humanistycznych na Uniwersytecie Jagiellońskim. ludzi w dalekich krajach są nam odległe. Być może zbyt odległe. Czy nie powinniśmy czynić więcej, aby poprawił się ich los? W jaki sposób to robić? Jest to problem poruszany w literaturze coraz częściej, wciąż jednak rzadko w kontekście etycznego konsumeryzmu1 ${ }^{1}$. Zastanawia, dlaczego etycy tylko wyjątkowo pochylają się nad moralnością wyborów rynkowych, biorąc pod uwagę, że to działania podejmowane przez prawie wszystkich mieszkańców krajów rozwiniętych, i to niemal codziennie. Jak szerokie konsekwencje posiadają i jaki zakres odpowiedzialności za nie spoczywa na konsumencie? W niniejszym tekście zostanie zbadane, czy etyka bezstronności, koncepcja prezentowana przez Petera Singera, nadaje się na filozoficzną postawę dla etycznego konsumeryzmu.

\section{Etyka bezstronności Singera}

Pojęcie „absolutnego ubóstwa” (ang. absolute poverty) zaproponował Robert S. McNamara, prezydent Banku Światowego. W 1973 roku

1 Zob. A. Lewicka-Strzałecka, Odpowiedzialność moralna $w$ życiu gospodarczym, Warszawa 2006, s. 169. 
w Nairobi wygłosił on przemówienie, w którym rozróżnił „ubóstwo relatywne” od „ubóstwa absolutnego”. Względnie ubodzy ludzie to mieszkańcy bogatych krajów posiadający mniejszą ilość zasobów niż ich zamożniejsi sąsiedzi. „Ubóstwo absolutne” oznacza „położenie życiowe charakteryzujące się chorobami, analfabetyzmem, niedożywieniem i nędzą, co uniemożliwia lub w istotnym stopniu utrudnia jego ofiarom spełnianie podstawowych funkcji życiowych” (oryg. „absolute poverty is a condition of life so degraded by disease, illiteracy, malnutrition, and squalor as to deny its victims basic human necessities") ${ }^{2}$. Według najnowszych dostępnych danych za mniej niż 1,90 dolara amerykańskiego dziennie w 2013 roku żyło około 10,7 proc. populacji świata, czyli 737 milionów ludzi ${ }^{3}$.

Cierpienie tylu osób nie jest obojętne etycznie. Singer, będący utylitarystą, rozpatruje je w kontekście użyteczności ${ }^{4}$. Argumentuje, że gdy nie wiąże się to z poświęceniem wartości o porównywalnym znaczeniu moralnym, postępująca moralnie jednostka powinna zrobić tyle, ile tylko może, aby zredukować ilość zła ${ }^{5}$. W obecnej sytuacji społeczno-ekonomicznej mieszkańców krajów rozwiniętych stać na towary luksusowe (rozumiane jako produkty, których kupowanie nie służy zaspokajaniu podstawowych potrzeb życiowych), podczas gdy osoby, które miały nieszczęście urodzić się w Burundi czy w Malawi, w ogromnej większości zmagają się z brakiem środków oraz dostępności podstawowych produktów spożywczych, lekarstw, czy nawet wody pitnej. Wniosek Singera wypływający z tego stanu rzeczy jest następujący: obywatele bogatych krajów, nie dając więcej środków na pomoc mieszkańcom rejonów skrajnie biednych, dopuszczają do ich cierpienia i śmierci. Jeśli więc zgo-

2 Zob. przemówienie: R. S. McNamara, Nairobi speech, http://www.juerg-buergi.ch/resources/ Archiv/Entwicklungspolitik-Archiv/Dokumente-zur-Entwicklungspolitik/McNamara_Nairobi_speech.pdf (30.08.2017).

3 Zob. strona internetowa Banku Światowego: http://www.worldbank.org/en/topic/poverty/ overview\#1 (30.08.2017).

4 Szersze omówienie utylitaryzmu jako postawy etycznej pojawi się w dalszej części pracy.

5 Zob. P. Singer, The Most Good You Can Do: How Effective Altruism Is Changing Ideas about Living Ethically, The Text Publishing Company, Melbourne 2016, s. VII. 
dzilibyśmy się, że dopuszczenie do śmierci osoby w żadnej sytuacji nie różni się moralnie od jej zabicia, to mieszkańcy krajów rozwiniętych (w przeważającej większości) byliby mordercami ${ }^{6}$.

Singer jednak nie stawia aż tak daleko idącego wniosku. Wskazuje na różnice pomiędzy nieprzeznaczaniem pieniędzy na organizacje charytatywne zajmujące się ratowaniem życia osób żyjących w skrajnym ubóstwie a celowym zabiciem kogoś. Inna będzie w tym przypadku przede wszystkim motywacja. Ponadto Singer zauważa, że bardzo trudne jest postępowanie $\mathrm{w}$ zgodzie $\mathrm{z}$ regułą nakazującą uratowanie tylu osób, ilu tylko możemy - wymaga to wyrzeczenia się wielu dóbr. O wiele łatwiejsze jest powstrzymanie się od zabijania. Kolejną różnicą jest większa pewność wyniku działania - gdy zdecydujemy się kogoś zabić, istnieje większe niebezpieczeństwo, że ta osoba umrze, niż gdy nie przeznaczymy pieniędzy na działalność dobroczynną. Co więcej, gdy je przekażemy, również nie mamy pewności, że ocalimy życie, gdyż mogą one zostać przeznaczone na projekt, który się nie powiedzie. Inną kwestią jest identyfikacja ofiary - zabijając kogoś, możemy wskazać na jednostkę pozbawioną życia, dopuszczenie do śmierci człowieka w dalekim kraju przez brak pomocy charytatywnej nie pozwala wskazać konkretnej ofiary, nawet jeśli można powiedzieć, że część z tych, którzy zmarli, zostałaby uratowana. Ponadto śmierć z głodu cierpiących ubóstwo ludzi nie jest spowodowana przez moje działanie, a śmierć osoby z powodu pchnięcia jej przeze mnie nożem już tak. Podsumowując, przeciw moralnej symetrii pomiędzy niewystarczającą pomocą charytatywną ze strony obywateli krajów rozwiniętych dla mieszkańców rejonów „trzeciego świata” a morderstwem, zdaniem Singera, przemawia: różnica w motywacji, wielkość wyrzeczeń, niepewność co do powodzenia akcji humanitarnych, brak możliwości zidentyfikowania ofiar oraz to, że do tragicznych skutków prowadzi nie działanie, lecz zaniechanie.

Rozbieżności pomiędzy obiema sytuacjami nie prowadzą go jednak do wniosku, że istnieje wewnętrzna różnica między zabiciem a dopuszczeniem do śmierci. Przedstawione powyżej różnice stanowią, jego

6 Zob. P. Singer, Etyka praktyczna, tłum. A. Sagan, Warszawa 2007, s. 209-213. 
zdaniem, różnice wewnętrzne, co oznacza, że uzasadniają one zachowania ludzi, ale nie usprawiedliwiają ich.

Zdaniem filozofa różnice w motywacji w przypadkach zabójstwa oraz nieprzekazywania pieniędzy na cele charytatywne są znaczące, ale nie wyłączają odpowiedzialności. Dla Singera przypadek opisywany w kodeksach karnych jako nieumyślne spowodowanie śmierci wydaje się być najbardziej zbliżony do nieudzielania pomocy charytatywnej. Sytuacji nie zmienia brak możliwej do zidentyfikowania ofiary. Nawet niepewność, czy przekazane pieniądze mogłyby komuś faktycznie pomóc nie sprawia, że można zaakceptować zaniechanie takiej pomocy. Odnosząc się do innego zarzutu, wskazuje, że ocalenie wszystkich, których można by ocalić, jest bardzo trudne do osiągnięcia i być może kontrskuteczne do zamierzeń byłoby stawianie ludziom bardzo mało realnych dla nich do osiągnięcia celów dotyczących działalności charytatywnej (jak na przykład przekazywanie dziewięćdziesięciu procent dochodu na cele charytatywne, jeśli okazałoby się, że tyle przekazujemy na dobra luksusowe - a tylko takie rozwiązanie uważa za moralne Singer), jednak jest to obojętne dla oceny wartości moralnej tego rodzaju czynów bądź ich braku. Prawdą jest ponadto, że na ogół czujemy się w obowiązku pomóc osobom, których nieszczęście spowodowaliśmy. Konsekwencjonalista, taki jak Singer, powie jednak, że odpowiadamy za wszelkie rezultaty naszych czynów, nawet tak odległe, jak to, że kupno luksusowego zegarka za pieniądze, które moglibyśmy przekazać organizacjom charytatywnym, doprowadzi do czyjejś śmierci. W tej sytuacji, zdaniem filozofa, nie ma znaczenia to, że gdybyśmy nigdy nie istnieli, to ta osoba także by umarła. Wynika to $\mathrm{z}$ tego, że konsekwencjonalista opisuje odpowiedzialność w świecie, jakim on jest, a nie jakim mógłby być.

W tym miejscu autor przechodzi do sformułowania argumentu przemawiającego za obowiązkiem udzielenia pomocy. Opisuje sytuację, w której dorosły człowiek spostrzega tonące w stawie dziecko. Mimo że wskakując do stawu, aby je uratować, spóźni się on do pracy oraz niewątpliwie zmoczy sobie ubranie, uznajemy, że nie ma to znaczenia wobec ocalenia dziecka. Dopuszczenie w tej sytuacji do jego śmierci byłoby moralnie porównywalne do zabójstwa. Taką ocenę można 
wesprzeć bardziej ogólną zasadą, brzmiącą: (1) „jeśli możemy zapobiec czemuś złemu, bez poświęcenia czegoś o porównywalnym znaczeniu, powinniśmy to zrobić" ${ }^{7}$. Następnie Singer powtarza niekontrowersyjną ocenę, mianowicie: (2) „totalna bieda (oryg. absolute poverty) jest zła". Większość mieszkańców rozwiniętych krajów ma możliwość, rezygnując z zakupu „tylko" luksusowych (nie niezbędnych dla nas do życia i pracy) dóbr, za zaoszczędzone pieniądze wspierać finansowo organizacje dobroczynne pomagające cierpiącym głód i choroby ludziom. W związku z tym filozof wysnuwa wniosek, że (3) „jest jakaś totalna bieda, której możemy zapobiec bez poświęcenia czegoś o porównywalnym znaczeniu moralnym”". Konkluzja brzmi więc: „powinniśmy zapobiec tej totalnej biedzie" 10 .

Przeciwko rozumowaniu Singera można wysunąć szereg zarzutów, zarówno w odniesieniu do jego założeń, jak i do ich praktycznych konsekwencji. Jednym $\mathrm{z}$ najistotniejszych w kontekście prowadzonych rozważań jest pytanie o to, czy postulowanie tak wysokiego poziomu pomocy nie spowoduje efektu przeciwnego do zamierzonego: ludzie będą postrzegać cel postawiony przez filozofa jako niemożliwy do osiągnięcia i przez to nie przekażą nawet mniejszych kwot. Czy w związku z tym w celu maksymalizacji udzielanej pomocy nie byłoby lepszą strategią stawiać sobie i innym niższe, ale i bardziej „realne” cele? Jest to zarzut, z którym sam Singer poniekąd się zgadza, uważa bowiem, że dla utylitarysty priorytetem jest dążenie do maksymalizacji udzielanej pomocy i możliwe jest, że głoszona przez niego etyka bezstronności może nie spełniać tego założenia.

$\mathrm{Z}$ rozważań oraz argumentów Singera sformułowanych w związku z problemem „absolutnego ubóstwa” można wyprowadzić wnioski, które są godne rozważenia także $\mathrm{w}$ powiązaniu $\mathrm{z}$ innymi zagadnieniami dotyczącym wpływu, jaki nasze działania lub ich brak mają na życie

7 P. Singer, Etyka..., dz. cyt., s. 220.

8 P. Singer, Etyka..., dz. cyt., s. 220.

9 P. Singer, Etyka..., dz. cyt., s. 220.

10 P. Singer, Etyka..., dz. cyt., s. 220. 
ludzi żyjących w innych rejonach świata. Zdaniem Singera mamy powinność starać się o poprawę losu osób w złym położeniu, niezależnie od szerokości geograficznej. Ponosimy odpowiedzialność za cierpienie innych, jeśli mogliśmy mu zapobiec, nawet gdy ofiara nie jest możliwa do zidentyfikowania ${ }^{11}$. Warto zastanowić się nad naszymi możliwościami i powinnościami w tym zakresie, zestawiając te wnioski z kwestiami dotyczącymi konsumpcji - codziennych wyborów dotyczących kupna towarów i usług. Jakie są nasze obowiązki etyczne jako konsumentów w sytuacji, gdy obserwując działalność firm, dostrzegamy wyzysk pracowników, zwierząt czy niszczenie środowiska naturalnego? Czy można wpłynąć na tę sytuację i jakie niebezpieczeństwa się z tym wiążą?

\section{Etyczny konsumeryzm}

Konsumentem każda osoba jest wówczas, gdy dokonuje czynności prawnej niezwiązanej ze swoją działalnością gospodarczą lub zawodową ${ }^{12}$. Uświadamianie sobie przez coraz szersze grono osób roli i znaczenia konsumpcji, połączone z rozwojem gospodarczym, który spowodował znaczny jej wzrost, doprowadziło do powstania ruchów konsumenckich. Te, poza walką o prawa kupujących, często podkreślają ich obowiązki - i tak etyczny konsumeryzm stawia sobie za cel uświadomienie konsumentom moralnego znaczenia ich wyborów ${ }^{13}$. W ostatnich latach powstało wiele organizacji zbierających dane o warunkach produkcji, dystrybucji czy testowania towarów ${ }^{14}$. Dużą rolę w tym procesie odgrywa też determinacja samych konsumentów, czerpiących informacje przede wszystkim $z$ Internetu. Istnieje wiele blogów oraz forów, których odwiedzający dążą do zebrania w jednym miejscu wiadomości

11 Pogląd Singera przytoczony na podstawie: P. Singer, Etyka praktyczna, dz. cyt., s. 204, 209-234.

12 Zob. art. 221 kodeksu cywilnego (Dz.U. $1964 \mathrm{Nr} 16$ poz. 93 z późn. zm.).

13 Zob. J. Kalajtzidis, Ethics of Social Consequences and Ethical Issues of Consumption, „Human Affairs” 2017 nr 27, s. 166- 177.

14 Przykładem może być brytyjska organizacja Ethical Consumer Research Association: http:// www.ethicalconsumer.org/ (30.08.2017). 
pozwalających im na dokonywanie etycznych wyborów ${ }^{15}$. Wśród podmiotów zbiorowych inicjujących bojkoty z pobudek nieegoistycznych znajdują się m.in. organizacje pozarządowe ${ }^{16}$ oraz kościoły i związki wyznaniowe ${ }^{17}$. Ruchom tym przyświeca przekonanie, że zakup konkretnego towaru jest wsparciem jego producenta, a więc i metod, którymi się posługuje w walce rynkowej.

W tym miejscu pojawia się pytanie o to, jak określić, czy działanie podejmowane przez danego wytwórcę jest etyczne. Pomocne będzie odwołanie do głównych nurtów współczesnej etyki ${ }^{18}$. Deontologia, jako etyka powinności, każe brać przy ocenie pod uwagę obowiązek, który w każdej sytuacji nakazuje postąpić w określony sposób. Twórca tegoż nurtu, Immanuel Kant, sformułował odpowiedź na pytanie ,jak postępować?” w formie imperatywu kategorycznego: „postępuj tylko według takiej maksymy, dzięki której możesz zarazem chcieć, ażeby stała się powszechnym prawem" ${ }^{19}$. Zupełnie inne kryterium dla oceny etyczności postępowania podmiotu przyjmują etyki konsekwencjalistyczne, a wśród nich utylitaryzm. Wśród jego twórców można wyróżnić Johna Stuarta Milla, który opisuje tę doktrynę jako naukę, „która przyjmuje jako podstawę moralności użyteczność, czyli zasadę największego szczęścia, głosi, że czyny są dobre, jeżeli przyczyniają się do szczęścia, złe, jeżeli przyczyniają się do czegoś przeciwnego. Przez szczęście rozumie się przyjemność i brak cierpienia; przez nieszczęście - cierpienie i brak przyjemności”20. Jednym z nurtów konsekwencjalizmu jest koncepcja określana jako etyka ekonomistyczna. Przedstawiciele tego stanowiska wychodzą z założenia, że racjonalny człowiek powinien dążyć do realizacji własnych korzyści. Wśród tych ostatnich może pojawić się działanie altruistyczne, ale osta-

15 Przykład forum, gdzie konsumenci wymieniają się informacjami na temat kosmetyków nietestowanych na zwierzętach: https://www.facebook.com/groups/1638940739682522/ (30.08.2017).

16 Zob. M. Friedman, Consumer Boycotts. Effecting Change through the Marketplace and the Media, New York 1999, s. 181.

17 Zob. M. Friedman, Consumer boycotts..., dz. cyt., s. 159-179.

18 Tematyka ta, $\mathrm{z}$ uwagi na ograniczenia dotyczące obszerności niniejszej pracy, zostanie jedynie zasygnalizowana.

19 I. Kant, Uzasadnienie metafizyki moralności, Warszawa 2002, s. 60.

20 J. S. Mill, Utylitaryzm, w: J. S. Mill, Utylitaryzm; O wolności, Warszawa 2005, s. 10. 
tecznie etyczność sprowadza się do bilansu zysków i strat dokonanego przez podmiot. Rachunek ten ma nie odwoływać się do kryterium uniwersalnej słuszności, a jedynie do subiektywnej opłacalności. Należy wskazać, że większość przedstawicieli utylitaryzmu (a także innych nurtów w etyce) odrzuca założenia etyki ekonomistycznej, krytykując jej redukcjonistyczny charakter oraz wskazując, iż „[P]rzekonanie, że moralność daje się zrozumieć jako działanie, w którym człowiek zawsze kieruje się opłacalnością, jest przejawem myślenia określanego jako imperializm ekonomiczny"21. Ponadto wskazuje się, że etyka utylitarystyczna powinna być bezstronna, czyli nie przedkładać szczęścia jednych członków społeczności ponad dobrostan innych ${ }^{22}$. Kolejnym odrębnym nurtem w etyce jest współczesna recepcja arystotelesowskiej koncepcji związanej z pojęciem arete, nazywana teorią cnót. Nie formułuje ona ogólnych zasad postępowania, lecz zwraca uwagę na osobisty rozwój każdego człowieka, z uwzględnieniem jego osobistych przymiotów. Podkreśla wartość umiaru, arystotelesowskiej idei „złotego środka” w każdej dziedzinie życia. Jest to etyka teleologiczna (od gr. telos - cel; to, ze względu na co następuje działanie), która zakłada, że przez praktykowanie sprawiedliwego życia można osiągnąć cnotę, określaną również jako dzielność etyczna, czyli działanie „we właściwym czasie, z właściwych przyczyn, wobec właściwych osób, we właściwym celu i we właściwy sposób” ${ }^{23}$.

W ocenie praktyk producenta można brać pod uwagę szereg czynników. Aniela Dylus wskazuje na trzy grupy „deficytów moralnych” w funkcjonowaniu przedsiębiorstw. Pierwszą stanowią czyny podejmowane wobec konkurencji. W drugiej grupie zawierają się nieuczciwe działania wobec konsumentów. Do ostatniej zalicza się naganne traktowanie pracowników ${ }^{24}$. Wszystko to w ujęciu prezentowanym przez ruch etycznego konsumeryzmu jest istotne dla oceny moralnej zakupu konkretnej rzeczy.

${ }^{21}$ K. Sosenko, Etyka ekonomii, w: Biznes, etyka, odpowiedzialność, red. W. Gasparski, Warszawa 2013, s. 112.

${ }^{22}$ Zob. J. Filek, T. Kwarciński, Etyka pożytku - utylitaryzm, w: Biznes, etyka..., dz. cyt., s. $140-153$.

${ }^{23}$ Cyt. za: D. Bąk, Teoria cnót, w: Biznes, etyka..., dz. cyt., s. 459.

24 Zob. W. Gasparski, Słowo wstępne, w: Biznes, etyka..., dz. cyt., s. 12. 
Co oczywiste, producenci przy wytwarzaniu towarów dążą do zapewnienia sobie maksymalnego zysku. Procesy globalizacyjne istotnie wpłynęły na metody, którymi się w tym celu posługują. Częstą praktyką jest przenoszenie produkcji w miejsca, gdzie jest ona bardziej opłacalna dla firmy ${ }^{25}$. Różnice w kosztach mogą wynikać z wielu czynników, spośród których najbardziej znaczącymi są dysproporcja w płacach (nierzadko niezapewniających pracownikom w biedniejszych rejonach świata nawet możliwości zaspokojenia podstawowych potrzeb rodziny) oraz rozbieżności dotyczące warunków zatrudnienia. Ponadto zniknęło powiązanie pomiędzy płacami pracowników wytwarzających towary a popytem na nie. Praca w fabrykach uruchamianych $\mathrm{w}$ krajach Trzeciego Świata odbywa się często $\mathrm{z}$ naruszeniem podstawowych praw pracowniczych. Fabryki, gdzie dochodzi do opisywanych praktyk, określane są w literaturze jako sweatshopy, czyli „fabryki lub warsztaty, zwłaszcza w przemyśle odzieżowym, gdzie pracownicy zatrudnieni są za niskie stawki, ich dzień pracy jest zbyt długi, a warunki pracy trudne" (oryg. „,A] factory or workshop, especially in the clothing industry, where manual workers are employed at very low wages for long hours and under poor conditions” ${ }^{26}$. Anna Lewicka-Strzałecka stwierdza: „w wielu przypadkach stwierdzenie, iż fabryka jest sweatshopem, jest raczej kwestią oceny etycznej niż prawnej"27. Warto zwrócić uwagę, że sweatshopy nie są problemem jedynie najuboższych rejonów świata. W Polsce, podobnie jak w całej Unii Europejskiej, nadal zdarzają się nadużycia wobec zatrudnianych imigrantów. Branże, w których najczęściej dochodzi do tego typu praktyk, to rolnictwo, budownictwo oraz usługi gastronomiczne i hotelowe ${ }^{28}$. Ponadto ogromnym problemem są niskie płace ${ }^{29}$

25 Zob. J. Kalajtzidis, Ethics..., dz. cyt., s. 168.

26 Sweatshop, https://en.oxforddictionaries.com/definition/sweatshop (24.07.2017).

27 A. Lewicka-Strzałecka, Odpowiedzialność..., dz. cyt., s. 154.

28 Zob. raport Agencji Praw Podstawowych Unii Europejskiej: Severe labour exploitation: workers moving within or into the European Union States' obligations and victims' rights: http://fra.europa.eu/en/publication/2015/severe-labour-exploitation-workers-moving-within-or-european-union (30.08.2017).

29 Zob. raport: Clean Clothes Campaign, Country profile: Poland, https://cleanclothes.org/livingwage/europe/country-profiles/poland/view (30.08.2017). 
(około 13 proc. ogółu zatrudnionych na umowę o pracę otrzymuje wynagrodzenie nieprzekraczające minimalnego) oraz duża liczba zatrudnianych na umowach cywilnoprawnych, bez umowy o pracę, co skutkuje mniejszymi gwarancjami prawnymi dla takich pracowników ${ }^{30}$.

Spojrzenie etycznego konsumeryzmu na osobę konsumenta jest zbliżone do wizji klasycznego liberalizmu. Friedrich August von Hayek pisze: „[W]olność oznacza nie tylko, że człowiek ma zarówno możliwość wyboru, jak i niesie jego brzemię; oznacza także, że musi on ponosić konsekwencje swoich czynów, otrzymywać za nie pochwały lub spotykać się z potępieniem" ${ }^{31}$. W tym ujęciu konsument ponosi pełną odpowiedzialność za swoje rynkowe wybory, może je kształtować dowolnie, w zgodzie nie tylko $\mathrm{z}$ tym, co uzna za opłacalne, ale i z własnym sumieniem. Przy zbieżnych założeniach, etyczny konsumeryzm przedstawia jako problem jednak to, co zwolennicy rynkowego liberalizmu uważają za jego największą siłę: „[K]onsumenci są wszystkim - oni są władcami i chcą być zadowalani. Dla przykładu: miliony ludzi lubią pić coca-colę, miliony ludzi lubią książkowe kryminały, «dreszczowce», kolorowe magazyny, walki byków, boks, whisky, papierosy, gumę do żucia. [...] Tym, co się liczy w ramach rynkowej gospodarki, nie jest akademicka ocena wartości, ale praktyczne wartościowanie dokonywane przez ludzi, wyrażające się w kupowaniu lub w powstrzymywaniu się od zakupów"32. Często bowiem, jak zostało powyżej wskazane, niska cena przy zachowaniu wysokiej jakości towarów osiągana bywa dzięki wyzyskowi. Wskazuje się na możliwości zmiany tego stanu rzeczy przez następujące działania konsumentów:

- kupowanie rzeczy produkowanych w sposób etyczny i przez to wspieranie ich producentów,

30 Zob. Główny Urząd Statystyczny, Wybrane zagadnienia rynku pracy (liczba osób z minimalnym wynagrodzeniem, samozatrudnieni, umowy zlecenia, o dzieło). Dane za 2016 rok, http:// stat.gov.pl/obszary-tematyczne/rynek-pracy/pracujacy-zatrudnieni-wynagrodzenia-koszty-pracy/ (30.08.2017).

31 F. A. von Hayek, Konstytucja wolności, w: Odkrywając wolność. Przeciw zniewoleniu umysłów, red. L. Balcerowicz, Poznań 2012, s. 227.

32 L. von Mises, Mentalność antykapitalistyczna, tłum. J. M. Małek, Warszawa 2012, s. 23-24. 
- niekupowanie towarów wytwarzanych z pogwałceniem standardów etycznych lub produkowanych przez firmy, których polityki moralnie się nie akceptuje, co przyczynia się do zmniejszenia popytu i strat wytwórców,

- nabywanie akcji jedynie takich przedsiębiorstw, które prowadzą swoją działalność etycznie,

- wpływanie na politykę firm przez udział w akcjach protestacyjnych i informacyjnych oraz publiczne wypowiedzi dotyczące ich działalności niezgodnej z etycznymi normami ${ }^{33}$.

Powyższe działania, gdy dokonywane przez większą liczbę osób, mogą skutecznie wpływać na trendy w działaniu firm z uwagi na masowość i wielkość konsumpcji.

Poza liberalną wizją roli konsumenta pojawia się pogląd, który stawia kupujących w pozycji raczej przedmiotu aniżeli podmiotu gry rynkowej. Nie jest to ocena pozbawiona uzasadnienia. Konsument bowiem znajduje się w gorszej od przedsiębiorcy pozycji wyjściowej. Wytwórca jest uprzywilejowany w sferze informacyjnej, finansowej czy organizacyjnej. Konsument podejmuje decyzje sam, bez konsultacji, często wobec własnych ograniczonych zasobów czasu oraz finansów. Biznes zresztą nie tylko posiada od kupującego większe środki, ale i wykorzystuje je w sposób pogłębiający jeszcze nierówność relacji rynkowych. Klient jest bowiem adresatem bardzo zaawansowanych i niewątpliwie mających ogromny wpływ na jego decyzje strategii reklamowych oraz marketingowych. W końcu konsumpcja jest rezultatem działań wielu niepowiązanych ze sobą jednostek, których decyzje często bywają przypadkowe czy chaotyczne, w przeciwieństwie do przemyślanych strategii biznesowych ${ }^{34}$. Powyższe nie uszło uwadze ustawodawcy. Systemy prawne państw rozwiniętych zapewniają konsumentowi w relacji z przedsiębiorcą daleko idącą ochronę $e^{35}$.

33 Zob. A. Lewicka-Strzałecka, Odpowiedzialność..., dz. cyt., s. 120.

34 Zob. A. Lewicka-Strzałecka, Odpowiedzialność..., dz. cyt., s. 121.

35 Por. uregulowania zawarte w tytule trzecim trzeciej księgi kodeksu cywilnego (Dz.U. 1964 $\mathrm{Nr} 16$ poz. $93 \mathrm{z}$ późn. zm.) oraz prawo unijne: https:/europa.eu/european-union/topics/consumers_ pl (30.08.2017). 
Opiekuńczy stosunek państwa wobec konsumenta wyraża się w kilku postulatach, dla założeń etycznego konsumeryzmu najistotniejsze $\mathrm{z}$ nich to:

- prawo do informacji,

- prawo do wyboru,

- prawo do wyrażania opinii,

- prawo do zaspokojenia podstawowych potrzeb,

- prawo do edukacji konsumenckiej ${ }^{36}$.

Prawo konsumenta do uzyskania informacji o produkcie wydaje się kluczowe, również, choć nie tylko, z punktu widzenia moralności zakupów. Jest jednak niemal niemożliwe do zrealizowania. Postuluje się prawdziwość, pełność, jasność, zrozumiałość i dostępność informacji ${ }^{37}$. Obecna technika i stopień wyspecjalizowania poszczególnych branż wykluczają równoczesne spełnienie tych zaleceń. Ponadto, nawet gdyby konsument miał komplet informacji o wszystkim, co związane z wytworzeniem, przechowywaniem, warunkami zatrudnienia $\mathrm{w}$ danej firmie (co wielce nieprawdopodobne), to często bez fachowej wiedzy nie będzie w stanie uzyskanych wiadomości ocenić.

Problem $\mathrm{z}$ dostępem do informacji rodzą też praktyki promocyjne. Choć zgodnie z koncepcjami wypracowanymi przez teoretyków marketing powinien służyć klientowi, to w praktyce często wyparty zostaje przez przeciwstawianą orientacji marketingowej orientację sprzedażową. Ta pierwsza wychodzi ze szlachetnych założeń - jej celem jest badanie potrzeb konsumenta i dostosowywanie do nich polityki firmy, a w konsekwencji budowanie jego zaufania do marki. Jednak promocja nastawiona na szybką sprzedaż przynosi natychmiastowe (choć krótkotrwałe) sukcesy, i dlatego jest tak powszechna w praktyce ${ }^{38}$. Podejmując decyzję,

36 Por. A. Lewicka-Strzałecka, Konsumenci: prawa i obowiązki, w: Biznes, etyka..., dz. cyt., Warszawa 2013, s. 259-268.

37 Zob. A. Lewicka-Strzałecka, Konsumenci..., dz. cyt., s. 261.

38 Por. A. Drapińska, Etyka marketingu - czy marketing jest etyczny?, „Zeszyty Naukowe Uniwersytetu Szczecińskiego, Problemy Zarządzania, Finansów i Marketingu” 2 (2016) nr 41, s. 229-239. 
konsument jest więc często pod wpływem wyrafinowanych technik, które mają jego wybór zdeterminować ${ }^{39}$.

Ponadto firmy w trosce o swój wizerunek dbają o nieujawnianie informacji, które mogłyby im w oczach klientów zaszkodzić. Jak pisze Lewicka-Strzałecka: „[W]iedza na temat sweatshopów jest skrzętnie ukrywana przed opinią publiczną i pozyskiwanie jej porównywalne jest z wysiłkami zdobywania informacji nt. obozów pracy funkcjonujących w ustrojach totalitarnych"40. Dowiedzenie się o takich procederach wymaga działalności whistlebloweró $w^{41}$ czy organizacji pozarządowych. Sprawia to, że informacje o tym, które korporacje dopuszczają się nieetycznych praktyk, są trudne do zdobycia, a pozyskana wiedza niemal $\mathrm{z}$ całą pewnością jest niepełna.

Kolejnym wartym analizy z perspektywy postulatów etycznego konsumeryzmu jest punkt zakładający prawo konsumenta do wyboru. Wraz ze wzrostem znaczenia etyki w produkcji poszerza się zakres regulacji prawnych stawiających wytwórcom bezwzględne wymogi, a to oczywiście znacznie zawęża gamę dostępnych klientom opcji. Choćby znaczący rozwój prawa pracy istotnie zwiększa koszty wytwarzania towarów, a co za tym idzie - ich ceny. W tej sytuacji możliwość wyboru przez osoby o ograniczonych zasobach materialnych zostałaby zdecydowanie ograniczona - możliwe, że również zagrożone zostałoby ich prawo do zaspokojenia podstawowych potrzeb.

Wobec poddania wyborów konsumpcyjnych etycznej ocenie niezmiernie ważne jest także prawo do edukacji konsumenckiej. Można stwierdzić, że - zwłaszcza gdy dotyczy kwestii poruszanych przez etyczny konsumeryzm - pozostaje ono raczej w sferze postulató $w^{42}$. Nasuwa się ponadto pytanie, jak szeroki powinien być jej zakres. Przy obecnym stopniu profesjonalizacji produkcji nie wydaje się możliwe osobiste zbadanie każdej kupowanej rzeczy, wraz z jej składem, częściami itd.

39 Zob. A. Lewicka-Strzałecka, Odpowiedzialność..., dz. cyt., s. 129.

40 A. Lewicka-Strzałecka, Odpowiedzialność..., dz. cyt., s. 154-155.

${ }^{41}$ Whistleblowing - sygnalizowanie zachowań nieetycznych; zob. Słownik pojęć podstawowych, w: Biznes, etyka..., dz. cyt., s. 565.

42 Por. A. Lewicka-Strzałecka, Odpowiedzialność..., dz. cyt., s. 137, 141, 150. 
Pozostaje w tym względzie zaufać organizacjom konsumenckim czy informacjom znalezionym w internecie. Oba te źródła nie zawsze jednak okazują się rzetelne $e^{43}$.

Warto zauważyć również, że wszystkie wyżej wymienione prawa przysługują konsumentom $\mathrm{w}$ bardzo różnym stopniu $\mathrm{w}$ zależności od warunków. Odmienne wymogi prawne stawiane wytwórcom w oczywisty sposób wpływają na decyzje rynkowe ludzi, a nawet mogą pozostawić ich bez możliwości wyboru. Co więcej, występujące w nurcie etycznego konsumeryzmu porównanie kupującego do wyborcy ${ }^{44}$ jest niesłuszne, gdyż w wyborach mamy do czynienia $\mathrm{z}$ równością głosów, konsumentem natomiast można być $\mathrm{w}$ większym lub w mniejszym stopniu, w zależności od posiadanych zasobów. Wielkość dochodu wpływa zarówno na możliwość realizacji praw, jak i siłę oddziaływania danej osoby na rynku ${ }^{45}$.

\section{Podsumowanie - porównanie i ewaluacja omawianych poglądów}

Proponowane przez Singera spojrzenie na problem ubóstwa oraz etyczny konsumeryzm sprzeciwiający się wyzyskowi pracowników w krajach mniej rozwiniętych mają wiele wspólnego. Oba sposoby działania (co warte podkreślenia - wzajemnie się niewykluczające) bazują na racjonalnej kalkulacji - chęci wyboru najefektywniejszej metody walki ze złem na świecie. Singer mówi: maksymalizujmy nasze wsparcie dla organizacji charytatywnych, ponieważ jest więcej ludzi potrzebujących pomocy by przeżyć, niż tych, którym autentycznie obecnie pomagamy, a zwiększywszy indywidualną pomoc, bylibyśmy w stanie pomóc wszystkim. Etyczny konsumeryzm zachęca do ekonomicznego wsparcia jedynie takich firm, które stosują uczciwe praktyki wobec swoich pracowników, przy jednoczesnym bojkocie korporacji czerpiących korzyści

43 Zob. A. Lewicka-Strzałecka, Odpowiedzialność..., dz. cyt., s. 156-157.

${ }^{44}$ Zob. http://www.ethicalconsumer.org/shoppingethically/whybuyethical.aspx (30.08.2017).

45 Zob. A. Lewicka-Strzałecka, Konsumenci..., dz. cyt., s. 263. 
z wyzysku - w ten sposób zwiększymy dochody przedsiębiorstw postępujących etycznie, a zmniejszymy zyski tych drugich, dzięki czemu podjęcie działalności zgodnej z postulatami etycznych konsumentów stanie się opłacalne, na czym zyskają dotychczasowe ofiary złych praktyk, czyli w opisywanym przypadku - zatrudnieni dotychczas w sweatshopach. Na pierwszy rzut oka to rozumowanie wydaje się trafne.

Co warto nadmienić, w obu przypadkach bardzo istotnym czynnikiem dla realizacji zamierzonych celów jest mobilizacja większej liczby ludzi do podjęcia podobnych wyborów. Bieda, głód i wyzysk, którym chcemy przeciwdziałać, są zjawiskami masowymi, często wynikającymi z problemów systemowych, toteż jednostka - w pojedynkę - nie jest w stanie skutecznie zwalczyć tak ogromnych problemów (choć jej działanie może być doraźnie pomocne) ${ }^{46}$.

Kolejnym punktem wspólnym jest anonimowość potencjalnych beneficjentów podejmowanych czynów. Podmiot ma działać na rzecz osób zupełnie z nim niepowiązanych, ani więzami rodzinnymi, ani emocjonalnymi, ani społecznymi, ani nawet kulturowymi. Tym samym motywem w obu sytuacjach nie jest zysk podmiotu działającego, wręcz przeciwnie - można uznać, że poświęca on częściowo własne, mniejsze dobro na rzecz większego dobra szeregu nieznanych mu ludzi. Argument Singera dotyczący obowiązku udzielenia pomocy prowadzi jednak do przyjęcia porównywalnej odpowiedzialności za osoby w naszym otoczeniu, jak za te na drugim końcu świata. Pytanie jednak, czy wyprowadzanie tak daleko idących wniosków jest uprawnione. Warto także zastanowić się, czy argument ów zachowuje aktualność, gdy skonfrontujemy go z celami etycznego konsumeryzmu.

Dostęp do prawdziwej, pełnej, jasnej i zrozumiałej informacji jest podstawą dokonywania etycznych wyborów konsumenckich.

${ }^{46}$ Poza zakresem tematycznym tekstu znajduje się opis, jakie czynniki mają wpływ na omawiane zjawiska, więcej na ten temat można znaleźć np. w raportach Banku Światowego: World Bank, Causes of Poverty and a Framework for Action, https://openknowledge.worldbank.org/bitstream/handle/10986/11856/9780195211290_ch02.pdf (30.08.2017); World Bank, Poverty and shared prosperity 2016. Taking on inequality. Key Findings, https://openknowledge.worldbank.org/bitstream/handle/10986/25078/210958KeyFindings.pdf (30.08.2017). 
Tymczasem, jak zostało wykazane wyżej, jest on obecnie w praktyce prawie niemożliwy, zwłaszcza gdy mowa o bardziej skomplikowanych produktach. Można tu oczywiście polegać na danych gromadzonych przez zajmujące się tym podmioty, ale bardzo trudno, zwłaszcza biorąc pod uwage proceder ukrywania przez korporacje informacji dotyczących stosowania praktyk wyzysku swoich pracowników, mieć pewność co do kompletności i rzetelności informacji posiadanych przez stowarzyszenia konsumenckie czy organizacje pozarządowe. Biorąc pod uwagę, że kupno - w warunkach wolnego rynku - to wybór między kilkoma opcjami, należy pamiętać, że brak wiedzy może prowadzić do sytuacji, w której pragnąc „ukarać” nieetycznego pracodawcę, wybierzemy towar produkcji jego konkurenta, z lepszym PR, ale niekoniecznie lepiej traktującego pracowników.

Trudno również przewidzieć skutki etycznych bojkotów konsumenckich. Zdarzają się wśród nich akcje zakończone pełnym sukcesem, jak poprawa warunków pracy w zakładach należących do firmy Nike. Przedsiębiorstwo to, w reakcji na konsumencką dezaprobatę dla ich działań, dokonało istotnych zmian w swojej polityce, co miało realny pozytywny wpływ na sytuację pracowników, którym np. w Indonezji podwyższono wówczas płace. Niestety często firmy w odpowiedzi na krytykę przenoszą produkcję w inne miejsca, i choć być może będzie ona odbywać się wówczas $\mathrm{z}$ większym poszanowaniem dla praw pracowniczych, to działania takie prowadzą do tragicznych skutków dla dotychczas zatrudnionych, którzy pozostają bez środków do życia i perspektyw zatrudnienia. Ogromnym problemem wciąż pozostaje także kwestia pracy dzieci. Etyczny konsumeryzm się temu sprzeciwia, jednak w wielu miejscach na świecie sytuacja ekonomiczna wciąż zmusza małoletnich do podejmowania pracy. Tragicznym przykładem jest historia niepełnoletnich zatrudnianych w zakładach odzieżowych w Bangladeszu. Gdy z powodu międzynarodowej krytyki zaprzestano tych praktyk, dzieci pozostały bez środków do życia ${ }^{47}$. 
Trudności w przewidzeniu skutków akcji prowadzonych w krajach rozwiniętych, a wymierzonych przeciw funkcjonowaniu sweatshopów w krajach rozwijających się, wynikają z czynników opisywanych powyżej: stopnia skomplikowania stosunków rynkowych, w tym samego procesu kupna towarów i usług oraz problemów prawnych, a także rzeczywistości społecznej zarówno w krajach bogatszych, jak i biedniejszych. Ponadto mamy do czynienia: ze znaczną odległością, która sprawia, że skuteczność używania instrumentów politycznych jest ograniczona, rozpiętością czasową i możliwą zmianą istotnych czynników pomiędzy działaniem a jego skutkiem, a także uczestnictwem oraz pośrednictwem innych osób, które jest konieczne do realizacji zamierzonych celów. Aby nasze działanie mogło wywrzeć wpływ na rzeczywistość, nie może bowiem pozostać odosobnione - im więcej osób przyłączy się do bojkotu czy protestu, tym większa szansa na osiągnięcie sukcesu.

Wszystko to prowadzi do pytania, czy zasada etyczna, zgodnie z którą oceniamy nasze czyny $z$ uwagi na ich przewidywane konsekwencje, prowadzi do wniosku przyjętego przez Singera: że ponosimy dokładnie tak samo dużą odpowiedzialność za dopuszczenie do cierpienia tuż obok nas, jak za bierność wobec krzywdy dziejącej się na drugim końcu świata. Na podstawie powyższych rozważań uprawnione jest stwierdzenie, że nie. W literaturze od dawna zauważa się, że skutki wszelkich podejmowanych przez nas działan są bardzo trudne do oszacowania, co prowadzi do trudności z maksymalizacją użyteczności nawet czynów dokonywanych w obrębie najbliższego otoczenia. To oczywiście tym bardziej stawia pod znakiem zapytania możliwość przewidzenia globalnych skutków działan ${ }^{48}$. Przypomnijmy rozumowanie Singera: (1) „jeśli możemy zapobiec czemuś złemu, bez poświęcenia czegoś o porównywalnym znaczeniu, powinniśmy to zrobić, (2) ,totalna bieda (oryg. absolute poverty) jest zła", (3) ,jest jakaś totalna bieda, której możemy zapobiec bez poświęcenia czegoś o porównywalnym znaczeniu moralnym", co prowadzi filozofa do wniosku, iż „powinniśmy zapobiec tej totalnej biedzie”. Należy zwrócić uwagę na problem związany z trzecią przesłanką. Singer

48 Zob. N. Szutta, Utylitaryzm wobec krytyki etyków cnót, „Diametros” 2017 nr 11, s. 46. 
usiłuje pokazać, że totalnej biedzie możemy zapobiec. Tymczasem przykład etycznego konsumeryzmu ukazuje, że skutki działań prowadzących do zapobieżenia cierpieniu dziejącemu się daleko od nas mogą okazać się inne od zamierzonych, a szansa na pozytywny rozwój sytuacji jest znacząco niższa, niż w sytuacji, w której przechodząc obok stawu, mamy do uratowania tonące dziecko. To sprawia, że trudno zaakceptować etykę bezstronności jako filozoficzną podstawę dla etycznego konsumeryzmu.

Co warto podkreślić, powyższe konkluzje nie muszą prowadzić do rezygnacji z konsekwencjalizmu, a jedynie do ograniczenia wymagań stawianych podmiotom. Możemy zwrócić uwagę na większe prawdopodobieństwo pozytywnych konsekwencji, na wartość samej dyskusji o problemie, konsekwencje polityczne itd. Warto jednak zróżnicować stopień odpowiedzialności ze względu na stopień prawdopodobieństwa wystąpienia oczekiwanego skutku, który jest (w większości sytuacji) tym wyższy, im bliższe sobie są miejsce i czas działania oraz oczekiwanych jego dalszych konsekwencji.

Co ciekawe, argument Singera dotyczący pomocy dla osób żyjących w absolutnym ubóstwie można by uzasadnić na gruncie etyki deontologicznej. Przy ocenie czynów z jej perspektywy wskazuje się, że najważniejsze - wobec uświadomienia sobie maksymy, z którą podejmowane działanie jest zgodne - jest zadanie sobie dwóch pytań: „czy możliwy jest świat, w którym ta konkretna maksyma mojej woli stałaby się prawem powszechnym"49 oraz „czy chciałbym takiego świata, to znaczy, czy chciałbym, by wszyscy, którzy znajdą się w podobnej sytuacji co ja, postępowali tak właśnie, jak skłonny jestem postąpić" ${ }^{50}$. Odpowiadając twierdząco w obu przypadkach, musimy uznać, że naszym obowiązkiem moralnym jest jak najszersza pomoc humanitarna oraz że powszechnym prawem można uczynić jedynie zakup towarów wytwarzanych w sposób niebudzący etycznych wątpliwości. Takie rozumowanie nie napotyka na najpoważniejszy z przytoczonych wyżej problemów, gdyż deontologia nie odwołuje się do pozytywnych skutków dla jak największej liczby

49 J. Filek, Etyka. Reinterpretacja, Kraków 2014, s. 119.

50 J. Filek, Etyka..., dz. cyt., s. 119. 
ludzi. Nawet więc, gdyby się okazało, że nasze działanie ma negatywne konsekwencje (co może się zdarzyć), dla deontologa nie będą one wpływały na ocenę moralną czynu.

Abstrahując od poglądu Singera, warto podkreślić, że etyczny konsumeryzm oraz zwiększenie pomocy humanitarnej dla krajów najbiedniejszych zarówno przy analizie konsekwencjalistycznej (przy uwzględnieniu wspomnianych wyżej jej ograniczeń), jak i w perspektywie deontologii bądź etyki cnót zasługują na pozytywną ocenę moralną. Należy jednak pamiętać o ograniczeniach, na jakie napotykamy: nasza jednostkowa wiedza co do działań na tak szeroką skalę jest ograniczona.

\section{Bibliografia}

Biznes, etyka, odpowiedzialność, red. W. Gasparski, Warszawa 2013.

Główny Urząd Statystyczny, Wybrane zagadnienia rynku pracy (liczba osób z minimalnym wynagrodzeniem, samozatrudnieni, umowy zlecenia, o dzieło). Dane za 2016 rok, http://stat.gov.pl/obszary-tematyczne/rynek-pracy/pracujacy-zatrudnieni-wynagrodzenia-koszty-pracy/(30.08.2017).

Drapińska A., Etyka marketingu - czy marketing jest etyczny?, „Zeszyty Naukowe Uniwersytetu Szczecińskiego, Problemy Zarządzania, Finansów i Marketingu" 2 (2016) nr 41, s. 229-239.

Filek J., Etyka. Reinterpretacja, Kraków 2014.

Friedman M., Consumer Boycotts. Effecting Change through the Marketplace and the Media, New York 1999, s. 159-181.

von Hayek F. A., Konstytucja wolności, w: Odkrywając wolność. Przeciw zniewoleniu umysłów, red. L. Balcerowicz, Poznań 2012, s. 227-269.

Kalajtzidis J., Ethics of Social Consequences and Ethical Issues of Consumption, „Human Affairs” 2017 nr 27, s. 167-177.

Kant I., Uzasadnienie metafizyki moralności, Warszawa 2002.

Lewicka-Strzałecka A., Odpowiedzialność moralna w życiu gospodarczym, Warszawa 2006. McNamara R. S., Nairobi speech, http://www.juerg-buergi.ch/resources/Archiv/ Entwicklungspolitik-Archiv/Dokumente-zur-Entwicklungspolitik/McNamara_ Nairobi_speech.pdf (30.08.2017). 
Mill J. S., Utylitaryzm, w: J. S. Mill, Utylitaryzm; O wolności, Warszawa 2005, s. 3-87. von Mises L., Mentalność antykapitalistyczna, tłum. J. M. Małek, Warszawa 2012. European Union Agency for Fundamental Rights, Severe Labour Exploitation: Workers Moving within or into the European Union States' Obligations and Victims' Rights, http://fra.europa.eu/en/publication/2015/severe-labour-exploitation-workers-moving-within-or-european-union (30.08.2017).

World Bank, Causes of Poverty and a Framework for Action, https://openknowledge.worldbank.org/bitstream/handle/10986/11856/9780195211290_ch02.pdf (30.08.2017).

World Bank, Poverty and shared prosperity 2016. Taking on inequality. Key Findings, https://openknowledge.worldbank.org/bitstream/handle/10986/25078/210958Key Findings.pdf (30.08.2017).

Clean Clothes Campaign, Country profile: Poland, https://cleanclothes.org/livingwage/ europe/country-profiles/poland/view (30.08.2017).

Singer P., Etyka praktyczna, tłum. A. Sagan, Warszawa 2007.

Singer P., The Most Good You Can Do: How Effective Altruism Is Changing Ideas about Living Ethically, The Text Publishing Company, Melbourne 2016.

Sweatshop, English Oxford Living Dictionaries, https://en.oxforddictionaries.com/definition/sweatshop (30.08.2017).

Szutta N., Utylitaryzm wobec krytyki etyków cnót, „Diametros” 2017 nr 11, s. 40-60.

Ustawa z dnia 23 kwietnia 1964 r. - Kodeks cywilny (Dz.U. 1964 Nr 16 poz. 93 z późn. zm.). http://www.worldbank.org/en/topic/poverty/overview\#1 (30.08.2017).

http://www.ethicalconsumer.org/shoppingethically/whybuyethical.aspx (30.08.2017). https://europa.eu/european-union/topics/consumers_pl (30.08.2017). https://www.facebook.com/groups/1638940739682522/ (30.08.2017). http://www.ethicalconsumer.org/ (30.08.2017). 


\section{Abstrakt \\ Etyka bezstronności Petera Singera jako filozoficzna podstawa dla etycznego konsumeryzmu?}

Praca bada, czy proponowany przez Petera Singera ideał bezstronności w kwestii wyborów etycznych nadaje się na filozoficzną podstawę dla etycznego konsumeryzmu. W pierwszej części przedstawiony zostaje pogląd Singera dotyczący odpowiedzialności moralnej za bierność wobec cierpienia innych ludzi. Filozof argumentuje, że podmiot jest w tym samym stopniu odpowiedzialny za nieudzielenie pomocy osobie znajdującej się tuż obok niego, co człowiekowi przebywającemu na drugim końcu świata. Druga część pracy przybliża ideę etycznego konsumeryzmu, postulującą dokonywanie wyborów rynkowych $z$ uwzględnieniem etyki postępowania producenta towaru. Jako przykład nieetycznych praktyk dokonywanych przez część przedsiębiorców opisywany jest wyzysk pracowników w fabrykach określanych jako sweatshopy, mieszczących się najczęściej w krajach rozwijających się. Następnie, w kontekście praw konsumenta, ukazana zostaje faktyczna sytuacja kupującego na rynku oraz napotykane przez niego trudności, gdy stara się wspierać producentów, których postępowanie nie rodzi etycznych wątpliwości. Całość rozważań prowadzi do wniosku, że pogląd Singera o zrównaniu odpowiedzialności za bierność wobec cierpienia osób w bliskim otoczeniu podmiotu oraz oddalonych od niego nie może zostać zaakceptowany jako podstawa dla etycznego konsumeryzmu. Na etapie podejmowania decyzji konsumenckiej w praktyce niemożliwe okazuje się uzyskanie pełnej, zrozumiałej i prawdziwej informacji na temat towaru. Ponadto, aby osiągnąć zamierzony cel konieczne jest zmobilizowanie większej liczby osób oraz dotarcie z postulatami do adresatów, którzy są władni doprowadzić do ich urzeczywistnienia. Ostatecznie skutek również jest niepewny - w przeszłości miały miejsce bojkoty konsumenckie, które doprowadziły do pogorszenia sytuacji wyzyskiwanych pracowników.

\section{Słowa kluczowe}

etyka bezstronności, etyczny konsumeryzm, Peter Singer, ubóstwo, sweatshop 


\section{Abstract \\ Can Peter Singer's Ethics of Impartialitybe the Philosophical Basis for Ethical Consumerism?}

The paper confronts Peter Singer's ideal of impartial ethics with the idea of ethical consumerism. The first part shows the view of Singer concerning moral responsibility for passivity in the face of others' suffering. The philosopher argues that an agent is responsible for not providing help to a person standing next to him in the same way as he or she is responsible for not doing it for someone on the other side of the world.

The second part describes the idea of ethical consumerism, which postulates buying things only when there is no ethical concerns to the process of their production. Sweathops are shown as an example of unethical practices. In the context of consumer's rights, there is a depiction of consumer's real position on the market and difficulties he meets when trying to buy ethically. The paper leads to a finding that Peter Singer's view concerning equal responsibility for not providing help to suffering, no matter where the person is, is impossible to accept. When the consumer's decision is taken he cannot obtain full information on the product. What is more, there is a need of similar behavior from a lot of other people and a decision from the bosses of the company to achieve change. At the end, the result of everything may be - and it happened in the past - worse for suffering people than their situation at the beginning.

\section{Keywords}

impartial ethics, ethical consumerism, Peter Singer, poverty, sweatshop 